\title{
EEN EN ANDER OVER DE GROOTE STOOMVAARTLIJNEN.
}

Nauwelijks veertig jaren geleden verklaarde Dr. Lardner, destijds cen persoon van gezag op het gebied der scheepvaart, dat het voor stoomschepen ondoenlijk was, onder stoom alleen, de reis te maken van Engeland naar het vaste land van de Vereenigde Staten van Noord-Amerika, zonder onderweg kolen in te nemen. Hij beweerde dit in een lezing door hem te Liverpool gehouden. "As to the project - zeide hij o. a. - which was announced in the newspapers, of making the voyage directly from New-York to Liverpool, it is, I have no hesitation in saying, perfectly chimerical, and they might as well talk of making a voyage from New-York or Liverpool to the moon." Zulke profetieën aangaande het welslagen der eerste stoomvaart-ondernemingen op lange lijnen zijn sedert dien tijd door de feiten zelf wederlegd, en wel op eene wijze, die het allezins de moeite waard maakt, kennis te nemen van deze feiten. Te zamen genomen vormen zij de bouwstoffen voor een geschiedenis, die in meer dan één opzicht een belangrijk deel uitmaakt van de geschiedenis der beschaving.

Het nut der stoomvaartlijnen is niet beperkt tot dat van een versnelde handelsgemeenschap, maar strekt veel verder. Groote stoomvaartlijnen vormen wegen en kanalen te gelijkertijd. Wegen, die werelddeel aan werelddeel verbinden en een snel en geregeld personen- en brievenvervoer verzekeren. Kanalen, die een sterken stoot gegeven hebben aan de emigraties, die volksverhuizingen der negentiende eeuw, en dus gestrekt hebben om den wassenden stroom binnen zijne oevers te houden.

En behalve dit praktisch nut geeft haar bestaan aan volken en mensehen een voorbeeld, dat aantoont wat volharding en kennis vermogen tot stand te brengen.

In spijt van veel leerrijks in de geschiedenis der stoomvaartlijnen, mag het betwijfeld worden of er door ontwikkelde personen 
in Nederland genoeg belang gesteld wordt in de kennis en in den vooruitgang dezer vervoermiddelen en zeker is het, dat er over dit onderwerp luttel in onze taal is geschreven. Op meer populariteit kunnen beschrijvingen van de ontdekkingstochten naar de Poolzeeën of in het hartje van Afrika rekenen, die, schoon zij voor het oogenblik van meer belang zijn uit een wetenschappelijk dan uit een welvaartsoogpunt, toch het voordeel hebben de nieuwsgierigheid op te wekken en de zucht naar het avontuurlijke te prikkelen. Hoe het zij, ik wil trachten hier een kort overzicht te geven van het wezen van eenige der voornaamste stoomvaartlijnen.

De twee voornaamste brandpunten der groote Transatlantische stoomvaart zijn Liverpool en New-York. Tusschen deze beide plaatsen varen de stoomschepen van vijf maatschappijen, nl. die der Cunard, Iuman, National, Guion en White Star lijn.

In de eerste plaats zal ik van deze lijnen achtereenvolgens iats mededeelon.

\section{DE CUNARD LIJN.}

Nadat het schip Sirius bewezen had dat er voor eon stoomschip geen bezwaar in lag den Atlantischen Oceaan tussehen Engeland en Amerika over te steken, en de Great Western spoedig daarna, in 1838 , deed zien dat oen geregelde dienst tussohen genoemde landen zeer goed te verwezenlijken was, wilde het Britsche goeveruement een lijn in het leven roepen tusschen Liverpool en Halifax, om met behulp daarvan de mail geregeld te vervoeren.

Particuliere aanbiedingen ter levering van de noodige schepen bleven echter uit en eerst een openbare inschrijving leidde er toe met den laagsten inschrijver, die tevens voor het publiek de meest gunstige voorwaarden aanbood, in onderhandeling te tredon. Als minste inschrijvers traden vereenigd op: Samuel Cunard, George Burms en David Mc. Iver, de grondvesters der thans beroemde Cunard Company. Zij gaven het goevernementsplan een deugdelijker vorm en sloegen voor het mailvervoer tusschen Liverpool en Halifax, Boston en Quebec voorloopig halfmaandelijks vast te stellen, en ter bereiking van dit doel vier stoomschepen in de vaart te brengen. De jaarlijksche subsidie werd bepaald op 81,000 pd. st. In het contract was sprake van zware boeten op eventueele onregelmatigheden in den dienst, en tevens behelsde het de hiuderlijke voorwaarden, dat de sekepen geïnspeteord 


\section{$\mathbb{E} 1 \mathbb{2}$}

zouden worden door officieren van de Admiraliteit, dat de gezagvoerders uit dezen zouden gekozen worden en dat de booten zoo moesten ingericht zijn dat zij in oorlogstijd als troepenschepen dienst konden doen.

Dit contract duurde zeven jaren.

Den 4en Juli 1840 stoomde de Britannia van Liverpool en opende den dienst. $\mathrm{Zij}$ vormde, met de schepen Acadin, Caledonia en Columbia de toenmaals nog embryoüsche vloot der maatschappij.

De gemiddelde snelheid dezer booten bedroeg $8 \frac{1}{2}$ knoop $\left(^{*}\right)$ per uur, een snelheid die men voor een begin stellig niet klein kan noemen en die gaandeweg grooter werd toen de ondernemers nieuwe schepen lieten vervaardigen en de levensvatbaarheid der lijn ten volle was gebleken.

In de geschiedenis van de vloot der Cunard Company zijn drie periodes, zoo al niet scherp af te scheiden, dan toch aan te wijzen. De eerste loopt van 1840 tot 1864 . Daarin bezigde men het houten raderschip. Van deze soort was de Britannit de eerste cn de Arubia de laatste. De tweede periode loopt van 1856 tot 1862 , toen het ijzeren raderschip in $z$ wang was. Zij werd geopend door de Persia en gesloten door de Scotia. De derde periode begon in 1862. Het jjzercn schroefschip trad van toen af op den voorgrond.

In 1844 bracht de maatschappij de Cambria en de Hibernia in de vaart, schepen die met een gemiddelde snelheid van $9 \frac{1}{4}$ knoop per uur liepen, terwijl in 1848 , toen het ondubbelzinnig was gebleken dat het publiek steeds grooter snelheid en meer comfortable inrichting eischte, aan de vloot werden toegevoegd de Amerika, Niagara, Europa, Canada en kort daarna de Africa en Asia, welke schepen het traject aflegden met een gemiddelde snelheid van 101 knoop per uur.

Inmiddels werd het contract met het goevernement hernieuwd en de subsidie verhoogd. Deze bedroeg nu 7 pd. st. $10 \mathrm{~s}$. per ton vracht, doch daartegenover stond dat de dienst wekelijks moest plaats hebben.

Gelijk te verwachten was duurde het echter niet lang of het succes van de Cunardlijn deed concurrenten verrijzen, die zich niet ongenegen betoonden een weinig in dat succes te deelen of zoo mogelijk er zich geheel van meester te maken, een verschijnsel dat men dagelijks waarneemt, van af het kippenhok,

(*) Eén knoop $=1854$ meter. 
welks bewoonsters krijgertje spelen om een stuk brood, tot aan paleizen wier bewoners met bloedigen ernst kibbelen om een stuk land. De hebzucht heeft, als alles, niettemin haar goede zijde, vooral waar zij, gelijk hier, de gedaante aanneemt eener heilzame concurrentie.

$\mathrm{Na}$ het welslagen der Cunard onderneming was het Amerikaansch goevernement veel minder afkeerig geworden van subsidieverleening dan het eenige jaren vroeger bleek. Het was er op uit de mail te doen vervoeren door een nationale lijn van stoomschepen.

Over het al of niet wenschelijke van het verleenen eener rijkssubsidie aan ondernemingen van de soort als hier beschreven worden, is veel gezegd maar minder beslist. De ondervinding schijnt echter wel te leeren dat zij niet te onpas optreedt diàr waar een onderneming op touw gezet wordt wier gevolgen van groot belang kunnen wezen, doch waarvan de uitkomsten toch te twijfelachtig zijn om de risico geheel te laden op de schouders van particulieren zonder dezen te ondersteunen. Zulk een steun behoort dan ook niet tot de vele beschermingen die de uitwerking hebben van een giftdrank, welke een kortstondig rozerood op de wangen te voorschijn roept om daarna met onverbiddelijke gestrengheid een spoedigen dood of een kwijnend leven na zich to slepen.

Bij subsidieverleening dienen de omstandigheden in het oog to worden gehouden. In een groot land bijv. zal een subsidie aan eene maatschappij verstrekt niet altijd, en op den duur niet verhinderen dat andere van dezelfde soort, zonder subsidie, met de eerste kunnen concurreeren, doch in cen klein land wordt allicht een niet gesubsidiecrde onderneming naast eene van hetzelfde karakter die wel subsidie geniet, een onmogelijkheid en wordt dus eenigermate aan verder particulier initiatief de pas afgesneden. En toch kan een tijdelijke bescherming in zulk een klein land beslissend zijn voor het voortbestaan vau een nieuwe en pas ontluikende ondernem!ng. Terecht dan ook, mijns inziens, wordt gezegd in het verslag der commissie van enquête omtrent den toestand van de Nederlandsche koopvaardijvloot:

"Maar terwijl eene wijze staatkunde daar to lande (Engeland) in ondersteuning van Engelsche stoomvaartlijnen, ook op Nederland, den stoot gaf tot eene nieuwe ontwikkeling der koopvaardijvloot; terwijl zij tevens door eene ingrijpende tariefshervorming de seheepraart in de Engelsche havens wist te doen toenemen 
tot eene vroeger ongekende hoogte, wist de Nederlandsche Regering alleen den bestaanden toestand op te ruimen, maar zich geen gedragslijn roor te schrijven die de aanmerkelijke nadeelen der mededinging van zoo machtige vreemde naburen voor de Nederlandsche vlag mogelijk en winstgevend kon maken. De verschillende gedragslijn in Engeland en Nederland omstreeks 1850 door de Regering aangenomen werd in beide landen sedert standvastig gevolgd, etc." Op de rraag: is subsidie goed? Kan geen bevestigend of ontkennend antwoord gegeven worden. Wel is er aangetoond dat sommige stoomvaartondernemingen zich zonder subsidie moeilijk zouden hebben kunnen staande houden, doch bij tegenstanders van subsidie rijst de vraag of die ondernemingen wel even energiek gedreven worden als dergelijke ondernemingen die geheel op particuliere krachten steunen en die zich verheugen in een groote mate van welvaart, juist omdat de ondernemers, aan zichzelf overgelaten, inspanning nooit ontzien, hun schepen naar goedvinden gebruiken en niet gebonden zijn aan dikwijls lastige voorwaarden.

Hoe het zij, het goevernement der Vereenigde Staten was, nu ruim een vijf en twintigtal jaren geleden, niet ongezind subsidie te verleenen aan een stoomvaartlijn op Engeland en trad in onderhandeling met zekeren Collins, een Amerikaansch burger. Met hem werd een contract gesloten, waarin men bepaalde dat er twintig reizen per jaar zouden gemaakt worden door vijf groote stoomschepen. Daarvoor zou een subsidie uitgekeerd worden van 19250 dollars per reis. Weldra echter werd dit contract voor onuitvoerbaar verklaard. Men trad in nieuwe schikkingen en kwam overeen dat het aantal jaarlijksche reizen zou bedragen zes en twintig en de subsidie 33700 dollars per reis. In 1850 , dus tien jaren na het ontstaan der Cunard Company, bracht de Collinsmaatschappij vier booten in de vaart tusschen New-York en Liverpool n. l. de Arctic, Rallic, Atlantic en Pacific. Deze houten raderschepen waren zeer weelderig ingericht, met het gevolg evenwel dat de kosten van aanbouw de begrooting verre overtroffen. Op de snelheid viel, van de zijde van het publiek, evenmin iets af te dingen, aangezien deze 15 à 16 knoopen per uur bedroeg, een snelheid toenmaals niet geëvenaard wel is waar, doch voor de maatschappij niet voordeelig, want een besparing van éen à twee dagen op den afstand van New-York naar Liverpool kostte haar jaarlijks een millioen dollars. Een snelheid, zoo groot als de genoemde, viel echter bijzonder in den smaak van het publiek, 
vooral van het Amerikaansche, en $\nabla$ an daar dat door vele aan de Collins lijn de voorkeur boven de Cunard lijn gegeven werd. In elf maanden van het jaar 1852 werden vervoerd op de Collins lijn 4306 en op de Cunard lijn 2969 personen. Niettegenstrande dit aanvankelijk succes bedroeg in de twee eerste jaren het tekort der Collins maatsehappij 256453 dollars, terwijl veel aanzienlijker verliezen haar te wachten stonden. In 1854 werd de Aretic, die 233 passagiers en 135 man als equipage aan boord had, bij een dikken mist angevaren door het Fransehe schip $V e s t a$, met het gevolg dat zij zonk en er sleehts 14 passagiers en 31 matrozen gered werden. Twee jaar later onderging de Pacific een dergelijk lot. Nadat dit schip den 23sten Januari 1856 van Liverpool vertrokken was met 45 passagiers en 141 koppen als bemanning is er nimmer weder iets van vernomen. Het is door het noodlot getroffen .... men weet niet wanneer, en vergaan .... men weet niet waar. Waarschijnlijk heeft het schip op een ijsberg gestooten, is daardoor plotseling gezonken en heeft alle opvarenden met zich in de diepte gesleept.

De ondernemers, niet afgeschrikt door zulke verliezen, brachten een groot en uitstekend schip, de Adriatic, in de vaart en mochten er zich in verheugen dat ook de passagiers zich niet sterk om de plaats gehad hebbende zeerampen schenen te bekreunen.

Aldra bleek het echter dat de Collins lijn te wild geboren was en te wild geleefd had. Haar levensloop was een prachtig maar kortstondig vuurwerk welks slotstuk heette: Hulde aan de geldsehieters. In 1858 ging de maatschappij failliet met een zeer groot passief. Daarbij kwam dat het goevernement van verdere subsidie afzag, gedreven eensdeels door den naijver van verschillende steden der Unie op New-York, en anderdeels door de luide protesten van de eigenaars der zeilvloot tegen de bescherming aan de stoomvaart verleend.

De Collins lijn verdween weldra voor goed van het tooneel. Intusschen hadden de ondernemers der Cunard lijn niet stil gezeten. Wel is waar daalde na een tweejarig bestaan der Collins lijn de subsidie der Cunard Company tot op 4 pd. st. per ton vracht, maar toch bracht deze maatschappij in 1852 de Arabia in de vaart, terwijl in 1855 voor haar rekening de Persia gebouwd werd, die tegen de Adriatic in snelheid en inrichting moest opgewassen zijn. De Persia was het eerste ijzeren schip der Cunard lijn en ook het eerste ijzeren zeeschip door Napier gebouwd. De grootte en snelheid der schepen ging tot 1862 steeds creseendo. Zoo was de 
Scotia, in 1862 voor de maatschappij gebouwd, alweder van grooter afmetingen dan de Persia. Doch daarmee was een keerpunt bereikt. De China, de Cuba, de Java en de Russia, die op de Scutia volgden, alle van ijzer en nu voorzien van een schroef als voortstuwer, waren van kleiner afmetingen dan de Scotia en kwamen spoedig na elkaar in de vaart. Zij voldeden zeer geed. De Russin o. a. maakte een reis van New-York naar Queenstown in dèn tijd van 8 dagen en 28 minuten. Na 1868 was de Cunard Company er weder op uit het laadvermogen harer schepen, bij den zich gestadig uitbreidenden handel, te vergrooten zonder de snelheid te verminderen, en op de Russin volgden dan ook spoedig de grootere schepen Calabria, Algeria en Abyssinia, terwijl in 1874 de Bothnia en Scythia, behoorende tot de prachtigste schepen van onzen tijd, de kroon op het werk zetten. Deze beide zusterschepen, die 130 meter lang zijn, kunnen elk 120 eerste- en 1100 derdeklasse passagiers $\left(^{*}\right)$ vervoeren. In de groote salon is ruimte, dic toelaat 300 personen aan tafel te plaatsen. Behalve door groote sterkte munten deze schepen uit door doelmatige en gemakkelijke inrichting, door ruimte, licht en ventilatie, welke desiderata zoo vaak onvervuld blijven.

Nog liet de maatschappij in 1875 de niet minder fraaie schepen Saragossa en Cherboury bouwen, zoodat zij thans in het bezit is van 49 stoomschepen met een totale tonnemaat van 90208 ton en cen totaal vermogen van 14537 nominale paardekracht. Van deze zijn er drie en twintig, met een totale bruto tonnemaat van 64718 ton en een vermogen van 10000 nominale paardekracht, in de Noord-Transatlantische vaart. Dat deze getallen iets beteekenen zal men inzien als men weet dat in 1871 de totale tonnemaat van alle Nederlandsche stoomschepen bedroeg 36644 en van Hamburgsche 45669 ton. ( $\dagger$ ) Niettegenstaande de schepen dex Cunard Company van Liverpool op New-York en terug in 35 jaren 2000 à 3000 overtochten gemaakt hebben heeft zij door zeerampen nimmer cen enkelen passagier of een enkelen brief verloren. Zulk een uitkomst is niet louter toeval, maar te danken aan de groote nauwgezetheid waarmede de dienst is geregeld. De schepen varen af op de minuut. Kapiteins en schepelingen krijgen instructies, die stipt nageleefd moeten worlen. Bij elke weersgesteldheid staan

(*) Het Eingelsche woord is "steeraue prassengers." Ous woord "tusschendekspassngiers" geeft de beteekeuis vau bet Lagelsehe niet juist termg.

$(t)$ Deze eijfers ziju slechts benaderend. 
mannen - trouw als de ganzen op het capitool - op den uitkijk, om zoo noodig mededeelingen te doen aan den officier van de wacht. De sloepen hangen vrij en zijn, even als de brandspuit, geheel gereed om dadelijk dienst te doen als dit vereischt wordt. Voor de Transatlantische vaart heeft de maatschappij 6000 menschen in dienst.

In 1873 werden door haar sehepen in 274 overtochten vervoerd: van Liverpool 9770 1e klasse en 46655 3e klasse passagiers; van Amerika 8540 1e klasso en 7646 3e klasse passagiers, dus totaal 72611 personen. In 1874 bedroeg dit aantal minder. n. l. 55200. De ladingen te Liverpool bestonden in 1872 voornamelijk in stukgoederen, machinerieën, ijzer en tin, bedragende totaal 210000 ton, terwijl naar Liverpool geladen werden: graan, levensmiddelen en katoen ten bedrage van 274000 ton, zoodat in één jaar het goederenvervoer dezer lijn een half millioen tonnen beliep.

Tegenwoordig vervoert de Cunard Company elken Zaterdag de mail naar New-York en enken Dinsdag naar Boston. Soms steken vier harer booten in één week van wal.

Met welke reuzenschreden de stoomvaart vooruit is gegaan sedert 1840 kan een vergelijking leeren tusschen de Britannia, gebouwd in 1840 en de Bothnia, gebouwd in 1874. De laatste heeft hijna een veertienmaal grooter laadvermogen, kan 3,75 maal meer $1 \mathrm{c}$ klasse passagiers vervoeren, gaat anderhalfmaal sneller en bespaart per indicateurpaard per uur meer dan de helft aan brandstof. Als een enkele maatschappij met zulke getallen en daadzaken voor den dag kan komen, wordt het duidelijk dat door ondernemende en voorzichtige menschen zelfs groote bezwaren en moeijelijkheden met schitterend gevolg overwonnen kunnen worden.

DE INMAN LIJN.

Het is geen gemakkelijke zaak met juistheid te woorzien of de dienst eener op te richten stoomvaartlijn al dan niet aan de gekoesterde verwachtingen, zoowel financiëele als andere, beantwoorden zal. Kon men zich wapenen mel gegevens eener statistiek en staathuishoudkunde, die een ídeale hoogte bereikt hadden, dan zou het wellicht doenlijk zijn de loopbaan eener onderneming to voorspellen. Doch zoover zijn wij nog niet en de $19 \mathrm{de}$ eeuw zal deze niet bereikte hoogte wel als erfenis aan de 20 e vermaken.

Aan de stichters der Inman lijn, vroeger geheeten de Liverpool, New-York and Philadelphia steamship Company, komt de eer toe ECON 1878. 
dat zij hun sueces vooral te danken hebben aan juiste berekeningen en dat zij alle handelskansen nauwkeurig hebben overwogen, alvorens hun lijn op te richten. Reeds vroeger dan 1850 zou de Cunard Company concurrenten gekregen hebhen indien zij niet door subsidie daartegen gedekt was geweest, en met vrij groote zekerheid kan men zeggen dat de Collinslijn met haar den strijd om de hegemonie ter zee niet zou hebben aanvaard, indien zij niet eveneens door een ruime subsidie gerugsteund was geworden.

Toch was de Collinslyn niet de eenige die in 1850 de Cunardlijn op zijde of vooruit trachtte te streven. In datzelfde jaar nl. begon de Inman Company te Liverpool haar stoomvaartonderneming op Philadelphia. Zij had geen mailsubsidie, doch deed een gelukkigen greep door zich voornamelijk emigrantenvervoer ten doel te stellen. Toen toch was de emigratie door middel van stoomschepen nog niet in zwang. De Inman Company slaagde er echter in, door het oprichten van tal van agenturen over geheel Brittanje, de aandacht der landverhuizers met goed gevolg op hare lijn te vestigen. En behalve dat zij op deze wijs de behoeften des tijds te gemoet kwam, waagde zij het eon stap verder te gaan door kloekweg do schroef als voortstuwer voor hare schepen te kiezen, een waagstuk destijds, waar tegenover sombere voorspellingen zich behoorlijk in slagorde schaarden. De Inman Company kocht in 1850 haar eerste jjzeren schroefstoomschip, de Cily of Glasgow van de bouwmeesters Tod and Mac Gregor te Glasgow. Den 17den December van dat jaar stoomde het van Liverpool naar Philadelphia.

Dit schip, het eerste Transatlantische schroefschip, diende langen tijd als model voor de overigo aan de Clyde gebouwde Transatlantische stoomschepen, en zelfs is zijn verschil met de nieuwste en grootste vaartuigen meer een onderscheid in afmetingen dan in verhoudingen.

De maatschappij kocht in 1851 van bovengenoemden bouwmeester haar tweede schip, de City of Manchester, dat in zijn eerste dienstjaar een winst van $40 \mathrm{pCt}$. afwierp.

Tusschen de jaren 1851 en 1856 werden aan de lijn toegevoegd de ijzeren schroefschepen City of Baltimore, Kangaroo en City of Washington.

Drie der opgegeven schepen werden tijdens den Krimoorlog, na overeenkomst met de eigenaars, gebezigd door het Fransche gouvernement, dat voordeeliger voorwaarden aanbood dan het Engelsche.

In het jaar 1857 werd Philadelphia, als haven van aankomst, rerwisseld met New-York en kon de maatschappij geacht worden 
door haar kindsche jaren heen te zijn. Den altijd min of mecr gevaarlijken tijd van tanden krijgen was zij flink to boven gekomen. Dat overigens het geluk haar diende moet mon erkennen. Zij profiteerde bijv. van het mislukken der Collinslijn, door in plaats van deze, eenigen tijd als mail tnssehen Amerika en Engeland dienst te doen. Haar zeer snelle schepen verrichtten dit werk met groote regelmatigheid, en over een overtocht van zes dagen en een en twintig uren, dien de Ci/y of Paris in 1869 volbracht, zal ook wel de meest voortvarende tevreden zijn.

Terwijl in 1860 een wekelijksche dienst werd vastgesteld, breidde deze zich in 1863 uit tot een van driemaal in de veertien dagen en in 1866 zond de maatschappij des zomers elke week over en weer twee stoomschepen uit. Thans doet zij dit ook des winters.

Om er een denkbeeld van te geven welk aandeel de Inman Company neemt in het personenvervoer naar en van Amerika, vermeld ik dat in de jaren 1856 en 185785000 passagiers met haar sehepen den overtocht deden, cen aantal dat nagenoeg een derde is van het totaal aantal personen dat in die jaren den Atlantischen Oceaan overstak.

Ook is misschien het volgend stantje hier zijn plaats waard. Aantal passagiers in 1870 van Engeland naar New-York vervoerd:

\begin{tabular}{|c|c|c|c|c|}
\hline N & $\begin{array}{l}\text { Aantsl } \\
\text { reizet. }\end{array}$ & $\begin{array}{c}\text { Aantal } 1 \mathrm{ek} \text {. } \\
\text { passoutgiers. }\end{array}$ & $\begin{array}{c}\text { Antul } 3 e \mathrm{kl} \\
\text { pussigiers. }\end{array}$ & Totaal. \\
\hline Inman & 68 & 3635 & 40465 & 44100 \\
\hline National & 56 & 2442 & 33494 & 35936 \\
\hline Gaion & 55 & 1115 & 27054 & 28169 \\
\hline Auchor & 74 & 1637 & 23404 & 25041 \\
\hline Cunard & 70 & 7638 & 16871 & 24509 \\
\hline
\end{tabular}

Wie eenige afmetingen van een paar der grootste schepen van de Inmanvloot wil nagaan verwijs ik naar Engelsche tijdsehriften. Hier bepaal ik er mij voornamelijk toe iets mede te deelen over de inrichting dier sehepen. De City of Chester en de City of Richmond, in 1873 in de vaart gebracht, zijn schepen van 139 meter lengte en 13 meter wijdte, met lange rijen hutten voor pasagiers en bemanning midscheeps geplaatst. Tevens zijn zij voorzien van vertrekken, die bestemd zijn voor hospitalen. Met de kooktoestellen kan voor 1500 menschen gekookt worden en het stuurtoestel is zoowel door stoom als uit de hand in beweging te brengen.

Deze schepen worden echter door de City of Berlin, gebouwd in 
1874, overtroffen. Dit vaartuig volgt in grootte op de Great. Eraslem en is ingericht voor 200 te en $15003 \mathrm{e}$ klasse passagiers en emi granten. Zijn bemanning telt 150 personen en zijn salon, welke midscheeps is geplaatst, heeft bij een lengte van 13 meter een breedte van bijna even zooveel meters.

Dat in zulk een schip weelde en gemak weinig te wenschen overlaten behoeft nauwelijks gezegd te worden, en te midden van lucht en water zou men zich in een hotel verplaatst kumen achten, ware het niet dat de golven ook met het gewicht van zulk een gevaarte den spot drijven.

DE NATIONAL LIJN.

Een der populairste lijnen in Engeland is de National lijn, in 1863 door kooplieden en reeders te Liverpool gesticht. Van alle maatschappijen wier schepen den Atlantischen Oceaan bevoeren, was langen tijd de National Company de eenige die als naamlooze vennootschap optrad. Dit is daaraan toe te schrijven, dat de ondernemers van stoomvaart, aangelokt door het succes der eerste lijnen, gaarne alle winst voor zich en hun vrienden wilden houden. Volslagen heeft echter de National Company bewezen dat een stoomvaartlijn, gegrondvest op het beginsel van beperkte aansprakelijkheid, zich flink staande kan houden. Van het aanvankelijk kapitaal van $700.000 \mathrm{pd}$. st. werden goede dividenden uitgekeerd niet alleen, maar bovendien heeft de vennootschap een assurantiefonds van $200.000 \mathrm{pd}$. st. in het leven geroepen. Haar tegenwoordig eigendom wordt geschat op een waarde van $1,200.000$ pd. st.

Bij de oprichting der lijn waren de moeilijkheden niet gering. Op mailsubsidie viel niet te rekenen. De bestaande concurrentie was groot. De Transatlantische handel stond wegens den Amerikaanschen burgeroorlog genoegzaam stil. Nogtans verwachtte men dat deze oorlog weldra zou geëindigd zijn en de ondernemers der lijn stelden zich voor alsdan deel te nemen in den sterken handel op de geconfedereerde staten. Tegen verwachting hield echter de oorlog aan en daar kapitaal en schepen nu eenmaal voorradig waren, zag de "Company" af van haar plan een periodieke lijn tusschen Liverpool en de Zuidelijke Staten te stichten, maar besloot daarentegen mede te dingen in het passagiers- en goederenvervoer op New-York.

De schepen voor rekening der vennootschap gebouwd waren minder hestemd snelle reizen te doen, dan wel ingericht voor zeer 
aanzienlijk laadvermogen en passagiersvervoer. De ervaring heeft aangetoond dat de keus van dit model juist was.

In 1863 werden de operaties begonnen met drie der grootste schepen toen varende, nl. de ijzeren schroefschepen Lomisina, Virginia en Pemnsylvania. Reeds in het daaropvolgend jaar werd do vloot uitgehreid tot op zes schepen, waarmede een wekelijksche dienst werd onderhouden.

Brengt men de toenmaals gedrukte handelsstemming in rekening, dan kan men het succes der ecrste jaren volkomen noemen. Het gevolg van dezen uitslag was dat in 1865 twee schepen aan de vloot werden toegevoegd en dat tusschen 1865 en 1869 het getal stoomschepen andermaal met twee werd vermeerderd, terwijl het eerste Transatlantische schip met compound machines, de Holland $\left(^{*}\right)$, in 1869 door de National Company in de vaart werd gebracht. In 1871 volgden twee der grootste schepen van dien tijd, de Esypt en de Spain. Deze opsomming bewijst genoeg dat de onderneming een tijdperk van bloei was ingetreden, waarin zij zich thans nog mag verheugen. Haar vloot telt twaalf groote schepen, die gezamenlijk 1200 1e klasse- en 15,000 2e klasse-passagiers kunnen vervoeren.

Iederen Woensdag vertrekt een schip der lijn van Liverpool en elken Zaterdag één van New-York. Bovendien onderhoudt de National Company met zes stoomschepen een veertiendaagschen dienst tusschen Londen en New-York via Le Hâvre.

Tijdens den Abyssinischen oorlog werden eenige harer schopen als transportvaartuigen gebruikt.

Wijselijk staat bij de ondernemers veiligheid boven aan het programma en slechts in de tweede plaats komt snelheid in aanmerking. Van daar dat zij er zich op beroemen kunnen nimmer menschenlevens door zeeramp verloren te hebben, hoezeer hun schepen een half millioen personen vervoerden. De goede resultaten der onderneming zijn voor een deel te danken aan het beleid van den beheerder (manager) Macalister, die een uitgebreide kennis van den Transatlantischen handel in dienst van de Cunard

(*) De Holland was niet het eerste zeeschip mot compound-machines. 1) Pacitic Steam Navigation Company bezigde in 1856 reeds schejen net compunudmachines. Ook Alfred Holl, to Jiverpoul, de stichter van de blueiende (1cean Steumship Company, plaatste, ons!reeks 1865 zulke machines in zijn schepen en bewerkte daardour dat deze den afstand van hiverpool tot Mauritius ( 8500 mijlen) onder stom en zonder crgens to stoppeu, konden alfegger, 
Company opdeed. Een voorbeeld te meer dat keunis en overleg belangrijke factoren zijn in het welslageu van grootsche ondernemingen of liever nog noodzakelijke vereischten om zulk een onderneming niet te verlagen tot een waagstuk, maar in haar do kiem te leggen van resultaten, die gespierd en gezond voor den dag kumnen komen.

Deze uitweiding leidt er mij toe hier een kort verhaal in te lasschen van de geschiedenis eener lijn, die alles behalve op een schitterend bestaan kon roemen. Ik doe dit om den mogelijken waan weg te nemen dat het de stoomvaartondornemingen onzer naburen altijd voor den wind is gegaan.

De lijn, die ik op het oog heb, is de Galway lijn.

In 1859 stelde een maatschappij van Engelseho on Iersche heeren, zonder ondervinding en kemnis van stoomvaart, aan het Britseh goevernement vóór, tegen een sulsidie van 3000 pd. st. per reis, uit en thuis, de mail te vervoeren van Galway naar Portland, Boston of New-York via St. John. Daarbij zouden zij in zes dagen telegrafische berichten - de Atlantische telegraafkabel was nog niet gelegd - naar Britsch Noord-Amerika overbrengen. Naar aanleiding van dit aanbod werd een contract gemaakt. Vier schepen, gebouwd naar plannen door de Admiraliteit goedgekeurd, werdon besteld en kostten gezamenlijk 385,000 pd. st. $\mathrm{Zij}$ werden niet op tijd geleverd, en aangezien volgens het contract de postdienst in Juni 1860 beginnen moest, werd een schip, de Parana, gehuurd, dat op zijn cerste reis $15^{3}$ uur later dan het contract bepaalde te St. Johm en 1 dag $13_{\frac{3}{3}}^{3}$ uur te laat te NewYork aankwam. De Conuutult, een der bestelde schepen, vertrok in Juli naar Boston en kwam aldaar $22 \frac{1}{2}$ uur over den tijd. Op haar tweede reis ging zij verlorell. De Ilibernin kreeg op haar ecrste reis ernstige averij en werd buiten dienst gesteld, terwijl de Columbia, die door ijs eveneens averij verkreeg, 10 dagen noodig had om St. John te bereiken en 17 dagen 201 uur on te Boston te komen. In plaats van de Connangll werd de Prince Alberl gecharterd; tevens kocht de maatschappij in 1861 van de eigenaars der Collinslijn het uitmuntende schip Adriatic. Dit voer naar St. John in zes dagen en kwam te New-York met 1 dag $15 t$ uur minder stoomens dan het contract bepaalde. Op de terugreis volbracht het zijn overtocht van St, John naar Galway in 5 dagen 193 uur, een reis die wellicht de snelste is van alle welke over den Atlantischen Oceaan gemaakt zijn.

Na achttien maanden bleken echter de verliezen zoo aanzienlijk 
te zijn en was het zoo moeilijk nieuw kapitaal bijeen te brengen dat de maatschappij ontbonden moest worden. De aandeelhouders hadden hnn kapitaal genoegzaam geheel verspeeld.

Zulk een kortstondig bestaan bewijst dat hooge subsidie machteloos is dààr waar onkunde koning kraait, en deze onderneming geleek een zcepbel, die con oogenblik met prachtige kleuren schittert en dan uiteenspat.

DE GUTON LIJN.

De vennootschap: The Liverpool and Great Western steamship Company te Liverpool, beter bekend onder den naam van Guionlijn, had in vroeger jaren een vloot van twintig snelle zeilschepen, die voornamelijk bestemd waren voor emigrantenvervoer. Van daar dat deze maatschappij, in weerwil van de reeds bestaande mededingers, zonder buitengewone inspanning een stoomvaartlijn kon stichten, die op het overbrengen van emigranten mocht rekenen. Aan den Amerikaan Stephen Barker Guion is het initiatiof voor deze onderneming te danken. Met eenige zijner bloedverwanten was hij de eerste die te Liverpool de zwermen landverhuizers concentreerde en alles regelde wat met den overtocht in verband stond. In zijn functie was hij echter meer de agent voor de Cunard- en Nationallijn, die eerst later de emigratie onder eigen contrôle namen. Zij deden dit toen de heeren Guion en andere ondernemers in 1866 voor eigen rekening een stoomvloot in de vaart begonnen te brengen.

De aandeelen in deze onderneming zijn in het bezit van weinig personen en worlen an de beurs niet verhandeld. Met vier fraaic en snelvarende schepen opende de lijn haar dienst on wel met zulk een goed gevolg, dat binnen twee jaren nog vier schepen aan de vloot werden toegevoegd. Van deze zijn vooral de twee laatstgebouwde, de Montana en de Dakoka zeer snelloopend en prachtig ingericht. Zij hebben hun salon midscheeps on op het opperdek.

Telkens doen twee van deze acht schepen den dienst tusschen Liverpool en New-York, vice-versa, geregeld wekelijks, en het aantal personen door deze lijn vervoerd gaat het getal 300,000 reeds te boven.

Vermelding verdient dat van deze menschen geen cnkele dour een zeeramp is omgekomen, alsook dat de Guionlijn zich in weinig jaren tijds heeft weten op te werken tot een lijn van den ecrstou rang. 
Buridans, een wijsgeer uit de 140 eeuw, beweerde dat een ezel, tusschen twee hoopen hooi geplaatst, van honger zou onkomen als hij niet aan een van beide de voorkeur gaf. Deskundigen, die beweren dat de tijd ophanden is, waarin voor goed beslist zal worden tusschen het bestaan - in hoofdzaak althans - van stoom- of zeilvaart, achten wellicht den zeehandel in een dergelijk dilemma geplaatst, als waarin de ezel van den scholasticus kan verkeerd hebben, indien die handel niet kiest tusschen stoom of zeilon. Ik acht dit niet waar, ten minste zoolang niet een of andere uitvinding een geheelen omkeer brengt in het vervoer ter zee. De statistiek schijnt wel aan te toonen dat in de lantste jaren b. v. do tonnemaat der Engelsche zeilvloot zich soms sterker uitbreidt dan die der stoomvloot $\left(^{*}\right)$, doch dit is een streven, dat volstrekt niet in denzelfden zin behoeft door te gaan. De stoomvloot zal de zeilvloot niet verdringen, noch omgekeerd, maar wel zullen zij elkaar aanvullen. Hoe nu juist de grenzen loopen kan niemand zeggen, doch zeker is het dat waar bijv. op korteren afstand goederenvervoer met voordeel door stoomschepen plaats heeft, hetzelfde vervoer op zeer lange trajecten beter gediend kan zijn van zeilschepen. Bij den strijd om den voorrang treden de omstandigheden aan een of anderen kant als bondgenoot op. De gulden middelweg, ik bedoel hulpstoomvermogen, is, volgens de ervaring, voor koopvaardijschepen een vicieus stelsel.

Een afdoend bewijs dat in beide genoemde wijzen van voortstuweu, elk afzonderlijk, voordeel kan liggen, leveren de stoomvaartondernemingen, die ook in bezit zijn van een zeilvloot. De White Star lijn, even als de Guion lijn, behoort daartoe. Behalve haar stoomvaartlijn tusschen Liverpool en New-York, die toch ook voor goederenvervoer dient, heeft zij een zeilvloot van ijzeren klippers, die op Australië varen.

De tegenwoordige vennootschap, ook geheeten the Oceanic Steam Navigation Company (Limited) en gevestigd te Liverpool, ontstond eerst zes jaar geleden. Aandeelen van $1000 \mathrm{pd}$. st. werden genomen door de beheerders der lijn, Ismay, Imrie and Co. en door andere te Liverpool. Het was vooral eerstgenoemde heer, die, almee door zijn uitgebreide kennis van zaken, een krachtige

$\left(^{*}\right)$ De brito tonnemaat van zeilschepen in 1875 in Groot-Brittanje gebouwd, bedroeg 5000 ton meer dan in 1874, die van stoomschepen 114000 ton minder. 
Impulsie gaf aan de onderneming. Niettemin had hot publiek geen grooten dunk van het welslagen dezer stoomvaartlijn. Men achtte de concurrentie te groot en schiep andere bezwaren, welke echter door de uitkomst gelogenstraft werden. Het goederen- en personenvervoer dezer lijn is groot en haar schepen zijn modellen van snclheid en constructie. Zij werden niet, gelijk de meeste Transatlantische stoomschepen, gebouwd aan de Clyde, maar bij Harland and Wolff te Belfast, die niet gebonden waren aan een contract, doch in last hadden de sterkste en allerbeste schepen te leveren. Aan dit verlangen hebben zij voortreffelijk voldaan. De Ocernic, in 1870 gebouwd, het eerste schip der nieuwe lijn, was het voorwerp van veler nieuwsgierigheid en te recht, want de verwachtingen, die men er van koesterde, zijn niet teleurgesteld. Groote snolheid, gepaard aan groote sterkte, dus aan veiligheid tegen de winterstormen van den Atlantischen Oceaan, kenmerken dit sehip en de volgende schepen. Thans zijn er zes in de vaart tusschen Liverpool en New-Xork, en onder deze bekleeden de Germanic en de Brilannic een eerste plaats. De geheele lengte dezer schepen is ruim 142 meter. Zij kosten elk ongeveer 200000 pd. st. Deze prijs is stellig niet gering te noemen, doch men bedenke dat de schepen voorzien zijn van alles wat de nieuwste uitvindingen aan de hand gedaan hebben, en het er aan niets ontbreekt wat gemak kan opleveren! Men vindt er tot een barbier-salon toe. Zoowel voor 3e klasse passagiers als voor andere zijn hofmeesteressen aan boord. De vrouwelijke $3 e$ klasse passagiers hebben afzonderlijke compartimenten en de gehuwden eveneens.

De Britannic, die 1300 passagiers vervoeren kan en een bemanning heeft van 150 koppen, is ook nog opmerkingswaardig wegens een nieuwe constructie, die het gemakkelijk maakt haar schroef te lichten, (zie Engineering 20 Nov. 1874) en de Adriutic is een schip dat zijn beroemden Collinschen naamgenoot in snelheid overtreft.

De White Star lijn mocht zich spoedig na haar oprichting verheugen in het vervoer van een mail der Vereenigde Staten. Haar dienst is wekelijks en kenmerkt zich door regelmaat en orde, die veel bijgedragen hebben tot hare populariteit.

Slechts angstvalligen zullen aarzelen, uit haar wel jeugdig maar roemrijk verleden, een goede toekomst te voorspellen.

Onder het tiental lijnen, waarvan de titel van dit opstel spreekt, breng ik, behalve de reeds genoemde: de Allan lijn, de Royal 
West-India lijn, de Pacifie Steam Navigation Company, de Messageries Maritimes en de Peninsular and Oriental Company. Van deze zal ik in de volgende bladzijden een en ander mededeelen.

DE ALLAN GIJN.

In welke mate de handel op Canada in de laatste 35 jarerf is toegenomen, kan blijken uit de omstandigheid dat tot op 18407 of 8 zeilschepen van $300 \grave{a} 400$ ton voltoende vervoermiddelen waren, terwijl thans de Allan lijn alleen 25 stoomschepen en bovendien 13 zeilschepen bezit, die in de vaart op Canada zijn. Het totaal laadvermogen der vloot beloopt 70000 ton.

Geruimen tijd . was Alexander Allan te Glasgow de man, die met zijn schepen handel dreef op genoemde kolonie, doch na zijn dood stichtten zijn vijf zoons een "company." Zij waren er op uit een stoomvaartlijn op te richten tussehen Canada en het moederland. Reeds waren in 1852 twee schepen voor dat doel gebouwd, toen de Krimoorlog uitbrak en vertraging bracht in het plan. De twee schepen, die een schroef hadden en waarop dus werd toegepast het voortstuwingssysteem dat proefhoudend was bevonden, werden gebruikt als transportschepen gedurende den oorlog. Eerst in 1856 ondernam de firma, die den naam Montreal Ocean Steamship Company had aangenomen, een regelmatigen maildienst met vier schepen, en contracteerde met het Canadeeseh gouvernement dat zij des zomers elke 14 dagen de mail zou vervoeren tussehen Liverpool en Quebec en des winters tusschen Liverpool en Portland, omdat alsdan de St. Lawrence niet bevaarbaar is. In 1859 werd deze dienst wekelijks, en dit is hij thans nog. Ook vaart er om de 14 dagen een boot van Liverpool naar St. Johnvia Halifax, terwijl eenige schepen van de vloot des zomers een wekelijksche lijn vormen tusschen Glasgow en Canada. Volgens het laatste contract, loopende van $1873-1878$, is de jaarlijksche subsidie 126433 dollars.

De maatschappij heeft in de laatste jaren stoomschepen laten bouwen, die tot de grootste van onzen tijd behooren en bewezen hebben in snelheid voor vele andere niet onder te doen. De Polywesiun o. a. makkte op haar eerste reis in December 1872 den overtocht tusschen Quebec en Moville (Londonderry) in 7 dagen 18 uren en 55 minuten.

De geheele stoom- en zeilvloot der firma vertegenwoordigt eene waarde van 2000000 pd. st:

De stoomschepen zijn niet bij Lloyd's of de Underwriters ge- 
classeerd. Hun eigentars hebben eigen sterkteregels en deze zijn strenger dan die van Lloyd. Ter wille van de landverhuizing naar Canada vestigde de Allan Company in Groot Brittanje en Ierland meer dan 1000 agenturen. Zij behoort dus tot de ondernemingen die landverhuizing aanmoedigen. Ook verbeterde zij, meer dan andere lijnen, het verblijf van $3 \mathrm{e}$ klasse passagiers aan boord. Zij geeft afzonderlijke compartimenten aan mannen en vrouwen en zorgt dat, voor bediening der laatsten, hofmeesteressen aan boord zijn.

Thans heeft de Allan lijn een gewenschte hoogte bereikt, doch wie deukt dat alles van een leien dakje ging: vergist zich. De gevaarlijke vaart bracht groote verliezen met zich, terwijl ook het gebrek aan kolenstations een bron van bezwaar was. De laatste moeijelijkheid is uit den weg geruimd sinds de maatschappij er een vaartuig op na houdt, dat geregeld kolen aanvoert van Nova Scotia naar de depots te Quebec en Portland. Dit neemt niet weg dat men er op uit is zuinig kolenverbruik te bevorderen, en daarom werd bij wijze van proef, de Circassian voorzien van een machine met cylinders voor hoogen druk alleen en met een toenmaals nieuwe stoomschuifbeweging. In constructiekosten bereikte men daarmee wel besparing, doch ik durf niet zeggen of men veel succes gehad heeft met deze poging om weer iets te winnen op de nooit verzadigde ingewanden van een stoomschip.

DE ROYAL WEST-INDIA MAIL COMPANY.

Nadat de Oceaan, dat eindeloos monster, in spijt van veel verzet, ook stoomschepen had leeren torschen, bleek een betere gemeenschap met West-Indië dringend noodzakelijk. Daarom contraeteerde de Royal West India Mail Steam Packet Company in 1841 met den „Board of Admirality" voor het vervoer van de mail tussehen Engeland, West-Indie en de golf van Mexico. Voor een subsidie van 240.000 pd. st. 's jaars eischte het contract dat tweemaal 's maands een stoomschip zou varen via Corunna en Madeira naar het eiland Barbadoes en van daar naar verscheidene andere West-Indische plaatsen. Op al deze stations moesten op bepaalde tijdstippen de mails afgegeven worden. Voorts was men gebonden aan de ongelukkige voorwaarde, dat de gezagvoerders gekozen moesten worden uit de „Royal Navy."

De maatschappij, die gemachtigd was 15000 aandeelen van 100 pd. st. uit te geven, liet veertien stoomschepen tegelijk bouwen. Zij moesten zoo ingericht zijn, dat zij desnoodig zwaar geschut 
aan boord konden nemen. De uitrustings- en onderhoudskosten liepen, ook door gebrek aan ervaring van Mc. Queen, den ontwerper der lijn, zoo hoog, dat de aanzienlijke subsidie ontoereikend bleek en het eerste jaar een verlies opleverde van 79790 pd. st. Eenigermate was dit laatste feit ook daaraan toe te schrijven dat de kooplieden nog niet gewend waren aan de hooge vervoerkosten der stoomschepen en dus niet dadelijk van het aangeboden communicatiemiddel gebruik maakten.

Een tegemoetkoming voor de maatschappij was de nieuwe schikking dat het jaarlijks af te leggen aantal mijlen van 684816 op 392976 werd gebracht, ten gevolge waarvan de jaarlijksche uitgaaf van 360.000 pd. st. op 235.000 pd. st. daalde. Bovendien werd bepaald dat, wegens buitengewone omstandigheden, de subsidie kon stijgen met een som, $10.000 \mathrm{pd}$. st. 's jaars niet te boven gaande.

Dergelijke hooge subsidies vonden haar oorsprong in de begeerte van het goevernement de schepen in oorlogstijd te kunnen gebruiken, en deze geleken dan ook veel op de gouvernementsschepen van dien tijd.

Ondubbelzinnig toonde echter het publiek zijn ontevredenheid over deze ondersteuning en de kolonisten klaagden over onregelmatigheid van den dienst en ontoereikendheid van de inrichting der schepen voor passagiersvervoer.

In weerwil van de verliezen door de maatschappij in de beide eerste jaren van haar bestaan geleden, ging de ljjn sterk vooruit. Hot batig saldo was in 184394210 pd. st. en in 1844147749 p. st Het groeide sedert zoo aan dat in April 18482 pd. st. per aandeel werd uitgekeerd.

Minder gelukkig was de onderneming met haar schepen. $\mathrm{Zij}$ verloor er in de eerste acht jaren zes. De Isi. stootte in 1842 bij Bermuda op een rif, en zonk. De Solway, een der schoonste schepen, volgde in 1843 dit voorbeeld. Zestig personen kwamen om bij deze ramp, die 20 .mijlen westelijk van Corunna plats had. In 1844 stiet de Medina op een coraalrif bij Turks Island en verging. Op de Alicranes-riffen in de golf van Mexico ging in 1847 de Tweeth verloren, terwijl op dezelfde rotsen in 1849 de Forth verongelukte. De Actaeon leed in 1850 bij Carthagena schipbreuk en in $185 \mathrm{l}$ onderging de Amazon op haar eerste reis een lot dat verschrikkelijk was. Dit groote houten schip, door Green te Blackwall gebouwd voor den prijs van 100.000 pd. st., had 50 passagiers en 110 man equipage aan boord. Nauwelijks was het eenige uren in zee of de kussenblokken der wielassen liepen heet, met het gevolg dat 
er brand ontstond, die, aangeblazen door een hevigen wind, binnen weinige minuten elke poging tot blusschen ijdel maakte. Door den dikken rook benauwd ontvloden de machinisten de machinekamer en vergaten de machine te stoppen. Elkeen beseft dat akeliger schouwspel wel niet denkbaar is dan dat van een met personen beladen schip, hetwelk in stormweder, brandend en in volle vaart een wissen ondergang tegemoet snelt. Sommige der opvarenden gaven de voorkeur aan den dood in de vlammen, anderen kozen de golven tot graf en in het geheel brachten slechts 41 personen er het leven af ; zulke feiten doen menigeen huiveren voor de zee en terecht, doch des te heuglijker is laarom de wetenschap dat percentsgewijze de oceaan minder slachtoffers eischt dan het vervoer te land.

In 1850 werd het mailcontract vernieuwd voor tien jaren en de conditie gesteld dat de maatsehappij een maandelijksehen dienst naar Brazilië zou invoeren. Het aantal mijlen werd daardoor 547296 en de subsidie per mijl gereduceerd op $9 \mathrm{~s} .10 \mathrm{~d}$,, gevende een vermindering van 2 s. $5 \mathrm{~d}$. per mijl en een totale subsidie van 270,000 pd. st. 's jaars.

Vijf nieuwe sehepen, die een tienmijls vaart moesten loopen, werden bijgebouwd. Dien ten gevolge stegen de onkosten dat jaar van 264802 pd. st. op 403769 pd st. De onderneming bloeide nu echter welig. Ten bewijze hiervan strekke de mededeeling van het feit dat zij in 1851 de ondernemers van de spoorweglijn door de landengte van Panama ondersteunde met 25480 pd. st., voornamelijk met het oog op de opkomst van San Francisco. Ook deed een betere keus van kapiteins haar geen nadeel.

Het tweede contract werd in 1857 gewijzigd. Daarbij beging men de groote fout, tot voorwaarde te stellen dat de lijn, ter wille van het mailvervoer via Egypte naar en van Australië, zich in verbinding moest stellen met de European and Australian MailCompany, een onderneming die uitgeput was en op sterven lag.

Van meer belang voor het publiek was de tweede voorwaarde, inhoudende dat de reis naar Rio de Janeiro verkort zou worden en drie nieuwe schepen moesten toegevoegd worden. Men bereikte daarmee het voordeel dat de reis der postpakketten van Engeland naar Panama van 50 op 42 dagen gebracht werd en de terugkeerende schepen drie dagen te huis waren voor dat de uitgaande vertrokken. In 1864 werd andermaal het contract hernieuwd, de subsidie gebracht op 172914 pd, st. en de snelheid der schepen van de Westindische lijn op $10 !$ knoop per uur.

Vier jaren later werd overeengekomen dat men voartaan de 
schroef als voortstuwer zou kiezen in plaats van wielen. Tevens werd toen bepaald dat het goevernemont in de winst boren $8 \mathrm{pCt}$. zou deelen, doch nadat de pers haar stem verheven had tegen de hooge subsidies, werd die der maatschappij in 1874 gereduceerd op 84750 pd. st. 's jaars.

Intusschen had de maatschappij meer vrij spel gekregen. Zij kon zich ruimer bewegen. De pop was een vlinder geworden. Zij liet voortaan in plaats van houten raderschepen ijzeren schroefschepen bouwen. De Tagus on Moselle werden in 1871 bij John Elder and Co. besteld en de Trasmamian werd gekocht en door denzelfden bouwmeester van een compoundmachine voorzien. De oude machine verslond in 349 uren reis 1088 ton kolen en de nieuwe bracht het schip met ongeveer dezclfde snelheid in 338 uren naar St. Thomas en behoefde daarvoor 466 ton kolen.

Een wijziging in het beheer der lijn en het hezigen van zeer goede schepen gaven voorspoed aan de maatschappij, aan wier aandeelhouders soms $10 \mathrm{pCt}$. uitgekeerd werd.

De dienst van Southampton met mails, passagiers en lading is thans als volgt:

Den 2en van elke maand vaart een boot op West-Indië, Cuba, Mexico, Panama, Centraal-Amerika;

den $9 \mathrm{en}$ en 24en van elke maand is de route naar Brazilië en de Plata-rivier via Lissabon, Bahia, Rio de Janeiro, Monte Video, Buenos Ayres;

den 17en van elke maand is er communicatie met West-Indië, Belize, Panama, San Francisco on andere plaatsen, en den 10en van elke maand gaat over Barbadoes, Trinidad, Curaçoa en andere plaatsen een boot naar Colon.

DE PACIFIC STEAM-NAVIGATION COMPANY.

Hoewel deze onderneming zich voor cen goed deel tot kustvaart bepaalt, zijn toch hare resultaten leerzaam genoeg om hier een vermelding te rechtvaardigen.

Kapitaal niet alleen, maar ook veel kennis en ervaring was er noodig om, met kans op welslagen deze onderneming op te richten, wier ontwerper, William Wheelright, een stoomvaart beoogde tusschen de havens aan de Westkust van Noord- en ZuidAmerika en over de Stille Zuidzee naar China en Australië. Nadat Wheelright van het goevernement van Peru, Bolivia en Chili vergunning had gekregen de kusten 10 jaar lang met stoomschepen 
te bevaren, ging hij in 1840 naar Engeland, waar hem, na veel moeite, een kleine subsidie voor het mailvervoer toegezegd werd.

Het door de aandeelhouders bjjeengebracht kapitaal van 250000 pd. st. was te klein om aanvankelijk meer dan twee schepen in de vaart te kunnen brengen. Deze schepen waren onvolmaakt, wat bijw. daaruit blijken kan dat de laadruimte slechts 50 pet. van de bruto tonnemaat bedroeg. Gebrek aan brandstof was almede een groote moeijelijkheid. Wegens deze en andere redenen werd in de eerste vijf jaren een verlies geleden van 72000 pd. st., doch de aandeelhouders, waarvan de meesten in Liverpool gevestigd waren, lieten zich hierdoor niet afschrikken. De kantoren werden verlegrd van Liverpool naar Londen, en William Just werd beheerder der lij.j.

Het was echter reeds 1847 gew.erden toen de aandeelhouders zich voor het eerst mochten verblijden in een dividend ten bedrage van $2 \frac{1}{2}$ pet. Met het goevermement werd in 1850 een verandering in het contract gemaakt, tengevolge waarvan een halfmaandelijksche dienst tusschen. Valparaiso en Panama werd ingesteld en vier schepen bijgebouwd werden. De subsidie was toen 20000 pd. st. 's jaars. Ver van schitterend bleven echter de vooruitzichten en de aanvraag om subsidieverhooging, in 1853 gedaan wegens gestegen kolenprijs, bleef zonder gevolg.

Just ging in 1856 naar de Westkust om de dienst te reorganiseeren. In deze poging slaagde hij naar wensch. Hij voorzag do schepen der maatschappij met de toen nog nieuwe compoundmachines en bewerkte hierdoor een aanzienlijke brandstofbesparing.

Vreemd voorzeker, waren deze schepen ongeveer 12 jaar lang nagenoeg de eenige oceaanstoomschepen, die met dergelijke machines waren voorzien. Een conservatisme dus dat zichzelf verslond.

Sinds 1860 is het den stoom gelukt den handel der stille Zuidzee in de phase van den vooruitgang te brengen Meer en meer begon men de voordeelen van cen goede gemeenschap in te zien. Het viel dan ook de "Company" niet zeer moeijelijk in 1865 een " charter" te erlangen waarbij haar werd toegestaan de lijn uit te breiden tusschen de Westkust van Zuid-Amerika en de Platarivier.

Van toen af namen geruimen tijd de winsten voortdurend toe, zoodat in 1867 de amdeelhouders het belangrijk maar gewaagd besluit namen, de lijn uit te breiden in die mate, dat maandelijks van Liverpool uit via Straat Magelhan een stoomschip zou varen naar de Zuid-Amerikaansche Westkust. 
Gewangd was dit besluit, niet alleen omdat het kapitaal moest uitgebreid worden tot op $2,000,000$ pd. st., maar vooral omdat het twijfelachtig was of stoomschepen zulke lange reizen met groote snelheid en toch met voordeel konden doen. In 1869 bleken echter de winsten, afgeworpen door de vier nieuwe schepen, die tusschen Liverpool en Valparaiso voeren, voldoende te zijn om de reis halfmaandelijks to maken en te verlengen tot Callao.

De zeventien reizen, in 1870 door schepen dezer lijn gedaan met klimmend succes, ontlokten een besluit om de afvaart driemaal per maand te doen plaats hebben, terwijl deze wekelijks werden in 1871. Het kapitaal werd daartoe gebracht op $3,000,000$ pd. st. en de vloot vermeerderd met drie snelloopende zusterschepen van 3800 ton bruto inhoud, nl. de Cikimborazo, de Cuzco en de Garonne.

In deze bloeiperiode der maatschappij werd aan de aandeelhouders vaak 20 pCt. uitgekeerd, doch weldra bleek het dat men te ver was gegaan met de poging andere maatschappijen den pas aftesnijden en met de zucht het publiek te believen.

Het culminatiepunt was bereikt en op klimming volgde daling.

In 1871 werden tusschen Liverpool, Valparaiso en Callao 29 reizen gedaan met verminderde winst, en deze bedroeg in 1872 op 37 reizen nog minder.

De directeuren sloegen in Januari van laatstgenoemd jaar aan de aandeelhouders voor de vloot met vicr schepen te vergrooten, waarvoor 500,000 pd. st. noodig was. Dit voorstel werd aangenomen, terwijl een half jaar later bet kapitaal werd uitgebreid met $1,000,000$ pd. st., zoodat dit nu de enorme som vanl4,000,000 pd. st. beliep. In weerwil hiervan en in spijt van haar machtige vloot heeft de maatschappij een sterke concurrentie niet kunnen weren. De Royal Mail en de Messageries Maritimes doen zich vooral tegenover haar gelden en worden hoog gesubsidieerd. De Pacific Company moet daarentegen voor een betrekkelijke geringe subsidie de mail vervoeren over een lang traject en met groote snelheid, hetgeen van twijfelachtig voordeel is. Voegt men daarbij de omstandigheid dat de handel op de Westkust van Zuid-Amerika in den laatsten tijd veel slapper is geworden, dan baart het geen verwondering dat de maatschappij het aantal reizen van Liverpool beperkt heeft tot één in de veertien dagen en dat zij de snelheid minder makkte. Hiermeê is wel een verlaging van subsidie gepaard gegaan, doch men wint daarentegen aanmerkelijke besparing aan brandstof.

De vlont der maatschappif, die 44 schepen sterk is, telt prach- 


\section{3.)}

tige vaartnigen De Lbrrik en Lignuria zijn in 1873 gebouwd en hebben een laalvermogen van 4000 ton benevens inrichtingen tot vervoer van 800 derde-klasse-passagiers. Met deze schepen kan de reis van Liverpool naar Valparaiso in ruim veertig dagen gedaan worden.

Tegenwoordig liggen verscheiden schepen der maatschappij werkeloos, eeu ongerief dat zij met veel andere maatschappijen gemeen heeft, doch dat geen aanleiding kan zijn aan de toekomst der Pacific Company te twijfelen. Een weinig onvoorzichtigheid is in haar operaties niet te ontkennen, maar de handel der Stille Zuidzee zal vooruitgaan, en zelfs gelooven velen dat de wereldhandel zich daarheen verlegt en die zee bestemd schijnt de voornaamste weg naar Indie te worden.

Hoe dit zij, de misstappen der Pacific Company zijn leerzaam en zullen niet gelaakt worden dan door de dwergen van wie het heet dat zij, op de schouders van een reus staande, verder zien dan deze, maar die niettemin dwergen blijven.

\section{DE MESSAGERIES MARITIMES.}

De Messageries Maritimes is een maatschappij die door het Fransehe goevernement ter wereld is geholpen, sterke subsidie geniet en gezegd kan worden een monopolie te hebben van het vervoer ter zee door Fransche stoomschepen op haar trajecten. Het eerste contract dateert van 1851 en had tot uitvloeisel het vervoer per stoomschip van de Fransche mails naar Italië, de Levant, Griekenland, Egypte en Syrië.

Het hoofddoel van de uitbreiding der vloot en het tot stand brengen van een wekelijkschen dienst tusschen Marseille, Civita Vecchia en Napels in 1855, was, gemeenschap te onderhouden tusschen het departement van oorlog on de bezetting van Rome. De dienst werd na den Krimoorlog uitgebreid tot de Donau en de Zwartezeehavens, terwijl in 1861 een contract volgde, dat de voorwaarden behelsde van het vervoer der Fransche mails naar Indië en China. De vloot telde toen reeds over de veertig schepen en werd nog nitgebreid toen de sterke handel op het Oosten vorderde dat de dienst verdubbeld werd. Inmiddels had dezelfde maatschappij in 1860 een Transatlantische lijn ran Bordeaux op Brazilië en La Plata in het leven geroepen, die voor een subsidie van ruim $2,300,000$ francs jaarlijks, de mail naar genoemde landen vervoert met een snelheid van ruim tien knoopen per uur. De lijn telt een 
half dozijn schepen waarvan de eerstgebouwde raderschepen zijn. Maandelijks vertrekt een schip van Bordeaux via Lissabon naar Pernambuco, Bahia, Rio de Janeiro en Monte Video. De grootste dezer booten meten 3400 ton en hebben een vermogen van 600 nominale paardenkracht.

In 1871 bedroeg het aantal schepen der maatschappij 66 en het jaarlijks af te leggen aantal zeemijlen 443556 . Tegenwoordig meet de vloot, met inbegrip van eenige zeilschepen, 175000 bruto registertonnen. Vijf en dertig stoomschepen zijn in gebruik op de Middellandsche en Zwarte zee, vier op een lijn tusschen Londen en Marseille, zes op de Braziliaansche lijn en achttien op de lijn van Marseille naar Indië en China. Tot de laatsten behooren de groote en voortreffelijke schepen dnadyr en Irazaddy, welke op hun beurt overtroffen zallen worden door vier schroefstoomschepen, die in 1875 in aanbouw waren. Haar eerste groote stoomschepen heeft de maatschappij in Engeland laten bouwen, doch zij heeft thans eigen werven en bouwt daarop haar vaartuigen, die in het algemeen veel overeenkomst hebben met die der Peninsular and Oriental Company. De vaart der maatschappij strekt zich nu uit tot alle voorname havens der Middellandsche en Zwarte zee en tot die van Indië, China, Japan en Brazilië. Voor het mailvervoer over 631514 mijlen jaarlijks, ontvangt de Messageries Maritimes 15,000000 francs jaarlijksche subsidie.

De waarde der vloot bedroeg in 1874 ruim 108 mill. francs. De maatschappij mag de grootste van alle stoomvaartmaatschappijen heeten en zich beroemen op nauwgezetheid en regelmaat.

De peninsular and oriental steam-Navigation company.

Met de Peninsular Company, die in 1834 een stoomvaartonderneming van Engeland op Portugal had opgericht, sloot het Engelsehe goevernement in 1837 een contract, waarin bepaald was dat de maatschappij maandelijks de mail naar Gibraltar zou vervoeren tegen een jaarlijksche subsidie van $29600 \mathrm{pd}$. st. Dit contract was het fondament van de maatschappij, die thans de Engelsehe mails naar het Oosten vervoert. In 1840 wijzigde het Britseh goevernement de postdienst naar Oost-Indië en wilde het de brieven van Engeland naar Alexandrië vervoerd hebben en de pakketten niet te Gibraltar overladen, aangezien dit oponthoud veroorzaakte.

Het resultaat van een publieke uitbesteding was dat de Penin- 
sular Company de voordeeligste voorwaarden stelde en op zich nam den dienst te doen voor 34200 pd. st. 's jaars. Aldus waren twee maildiensten gecombineerd n. l. die van Engeland op Gibraltar en die van Gibraltar op Alexandrië. Van daar de naam Peninsular and Oriental Company.

Een paar jaren later contracteerde de regeering met de maatschappij dat tegen 115000 pd. st. 's jaars de lijn verlengd zou worden van Suez naar Madras, Ceylon en Calcutta en dat van Ceylon naar Penang, Singapore en Hongkong maandelijks een boot zou varen voor 45000 pd. st. 's jaars.

Deze stand van zaken duurde tot 1852 toen, na een nieuwe uitbesteding, de P. and O. Company aanbood het geheole brievenvervoer tusschen Indië en Australië op zich te nemen voor een jaarlijksche subsidie van 199600 pd. st. Na veel oppositie werd dit voorstel aangenomen, waarop de maatschappij haar vloot uitbreidde en op verhoogde snelheid bedacht was. Zij liet een groot schip, de Himalaya, bouwen, dat zeeklaar 132000 pd. st. kostte, benevens zeven schepen, die minder groot waren en gezamenlijk voor $650000 \mathrm{pd}$. st. geleverd werden. De dienst dreigde niettemin te lijden, omdat op verschillende stations de kolen schaars en zeer duur waren, doch hierin werd voorzien door wijziging van het contract. Behalve de bepalingen omtrent snelheid, boeten enz. was er ook eene waarin uitgedrukt stond dat aan boord van elk schip een dokter moest zijn.

Weldra werd de dienst gestoord door het uitbreken van den Krimoorlog. Elf schepen der maatschappij deden gouvernementstransportdienst, waarvan het gevolg was dat de lijn op Australië moest gestaakt worden, terwijl die op Bombay en China tijdelijk maandelijks in plaats van veertiendaags werd. Dit gaf aanleiding tot ontevredenheid van de kolonisten, die na den oorlog een eigen maildienst begeerden. Toen daarop in 1856 een nieuwe inschrijving volgde voor een maandelijkschen dienst tusschen Suez en Australië, bood een nieuwe maatschappij, de Australian Steam Navigation Company, de gunstigste voorwaarden aan. Zij nam op zich den dienst te doen voor een subsidie van 185000 pd. st. 's jaars en het goevernement nam dit aanbod aan.

Genoemde maatschappij maakte echter een droevig figuur. De directeuren hadden, in spijt van hooge geboorte of positie, weinig kennis van zeevaartkundige zaken. De lijn moest in 1857 geopend worden, doch de schepen waren niet gereed. Men was verplicht met de Royal Mail en andere maatschappijen te onderhandelen on 
toen de eigen schepen klaar waren bleken zij ongesehikt te zịin voor hun bestemming.

De 48 aandeelhouders hadden 500.000 pd. st. nominaal kapitaal, doch er was slechts voor 420.000 pd. st. ingeschreven.

Weldra bleek de onderneming alle levensvatbaarheid te missen en reeds in 1857 verklaarde zich de maatschappij insolvent. Zij had haar geheele kapitaal verloren.

In 1858 volgde weder een inschrijving voor maandelijkschen maildienst tusschen Groot-Brittanje en Australië met een zijtak tusschen Marseille en Malta. De Royal Mail Company schreef in voor $250.000 \mathrm{pd}$. st. en de $\mathrm{P}$. and 0 . Company voor $180.000 \mathrm{pd}$. st. jaarlịksche subsidie. Aan de laatste maatschappij werd de dienst gegund, die in 1859 geopend werd. Spoedig daarop werd het contract eenigszins gewijzigd en bepaald dat een maandelijksche lijn van Galle naar Sydney zou loopen, die, in verband met de Calcutta, Suez en China lijnen, de Australische kolonies zoowel in gemeenschap bracht met de voornaamste Indische havens als met het moederland. Dit contract duurde tot 1866 . Bij een nieuwe inschrijving was de $P$. and $O$. Company de eenige die een bod deed. Zij stond in voor een gemiddelde snelheid van 10 knoopen per uur en wilde den dienst halfmaandelijks doen voor een jaarlijksche subsidie van 170.000 pd. st.

Volgens het tegenwoordige contract gaat wekelijks een stoomschip met de mails van en naar Southampton door het Suez-kanaal. Voor al haar maildiensten te zamen, zich uitstrekkende over een traject van 1171092 mijlen, geniet de maatschappij een subsidie van 430.000 pd. st. 's jaars. De voornaamste havens in Indië, China, Japan en Australië die de schepen der P. and O. Company aandoen zijn: Madras, Calcutta, Penang, Singapore, Hongkong, Shanghai, Yokohama, Melbourne en Sydney.

Het geheele kapitaal der Company bedraagt 4,300.000 pd. st. verdeeld in 2000 aandeelen, die verspreid zijn over alle streken der wereld en waarvan een derde in het bezit is van dames. De schepen vertegenwoordigen een kapitaal van $3,757.000$ pd. st.; $221.000 \mathrm{pd}$. st. is noodig voor andere eigendommen als dokken etc. en de rest steekt in kolenvoorraad en levensmiddelen.

Van de 50 stoomschepen der vloot worden er 34 gebruikt in den dienst op de Middellandsche en Adriatische zee en in Indië en China; vijf doen locaaldienst in de Chineesche en Japansche zee en vier stoomen tusschen Ceylon, Melbourne en Sydney. De overigen zijn goederen- en reserve-schepen. 
De maatschappij verschaft werk aan 12,600 personen, ongerekend de kolenwerkers en " coolies."

In de laatste twintig jaren heeft de $P$, and $O$. Company slechts één jaar met verlies gevaren. Haar bruto-ontvangsten zijn zeer aanzienlijk en kwamen soms twee en een half millioen pd. st. nabij, doch de uitgaven zijn evenzeer enorm. Van daar dat de dividenden klein zijn in vergelijking van die van andere dergelijke maatschappijen, welke geen subsidie genieten maar geheel naar eigen goedvinden hun schepen gebruiken.

De kolen verslinden veel geld. De uitgaaf daarvoor was tusschen 1856 en 1865 , toen de prijs matig was, gemiddeld 525000 pd. st. 's jaars. Op de verschillende stations gezamenlijk is steeds een voorraad van 90000 ton aanwezig, welke aangevoerd wordt door 170 zeilschepen, die de maatschappij in gebruik heeft.

De Khedive is één der moderne schepen dezer "Company," die door het Suezkanaal gaan. Dit ijzeren schroefschip onderscheidt zich door een groot laadvermogen en betrekkelijk geringen eisch van loopende uitgaven. Het behoudt een tienmijls vaart en is keurig ingericht.

Men geloove niet dat het aantal groote stoomvaartondernemingen zich beperkt tot het vluchtig beschreven tiental. Zoo behooren bijv. eveneens tot de stoomvaartondernemingen van den eersten rang: de Compagnie Genérale Transatlantique, de Anchor lijn, de Norddeutsche Lloyd, de Hamburg-Amerikaansche Packetfahrt-Actien Gesellschaft, de Pacific Steamship Company etc., en wie ook op die van den tweeden en derden rang acht wil slaan, heeft een onafzienbaar veld vóór zich.

Op het gebied van groote stoomvaartondernemingen staat Engeland boven aan; dan volgen Frankrijk, Duitschland en Amerika. Ook Nederland is in de laatste jaren begonnen eenig gewicht in de schaal te leggen. Wel is ons aandeel nog bescheiden en mogelijk zal men beweren dat het hier teedere planten geldt die nog eenige misschien strenge winters, met veel zorg zullen moeten overgehouden worden, doch de troost is er dat een jonge struik kan opschieten tot een forschen boom die vruchten geeft. Dit neemt niet weg dat zich de vraag opdringt, waarom het zoolang geduurd heeft voordat men op het gebied van stoomvaartondernemingen zich in Nederland is beginnen te spiegelen aan den Engelschen nabuur. Of is ons vermogen tot doortasten te zeer verstompt? Ik weet het niet, doch wel weet ik dat we achterlijk zijn, zeer 
achterlijk, en dat zich de naneef nog zal schamen als hij erkennen moet dat zijn overgrootvader een rentenier was, die in den ${ }_{n} \mathrm{Kampf}$ um's Dasein" in de achterste gelederen wegschool, of die, als de ontrouwe dienstknecht, zijne talenten in Spaansche of Turksche aarde begroef.

Ik overdrijf niet. Men leze het verslag van de commissie van enquête omtrent den toestand van de Nederlandsche koopvaardijvloot, en oordeele dan of hier te veel is gezegd.

J. J. F. Pennink.

Wij voegen hierbij ten slotte nog eene opgave van afmetingen enz., van eenige voorname stoomschepen in de groote vaart, in de laatste jaren gebouwd, voor zooveel de besprokene lijnen en eenige andere betreft. 


\section{Gegevens van eeuige groote ijzeren schroefbooten, behoorende aan verschillende Maatschappijen.}

(Lengte, wijdte en holte zijn angegeven in Meters; de tounemaat in reg.-touneu van 2,831 M.;

t. 1. bet. tusscheu de loodlijnen; t. s. tot spardeck )

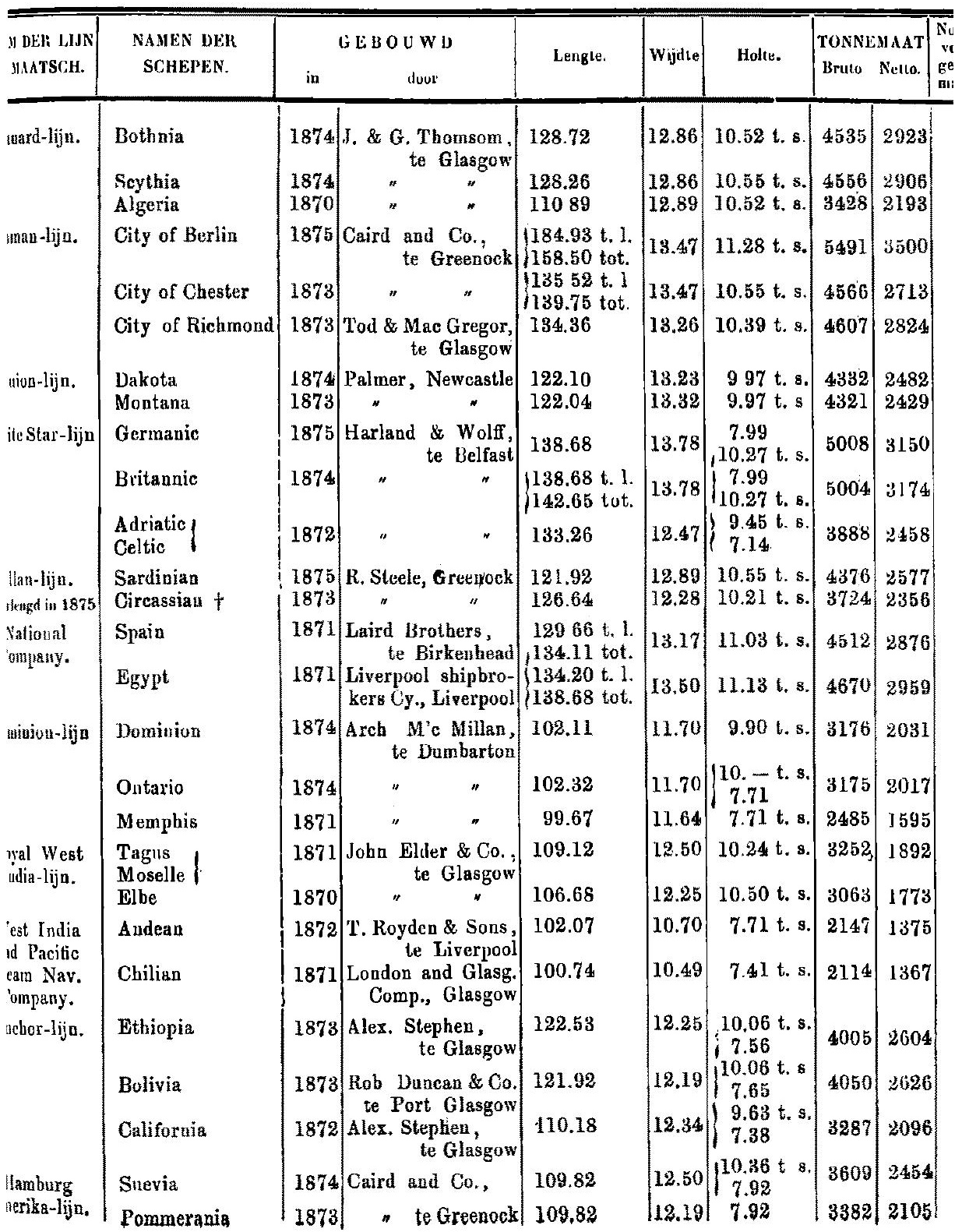




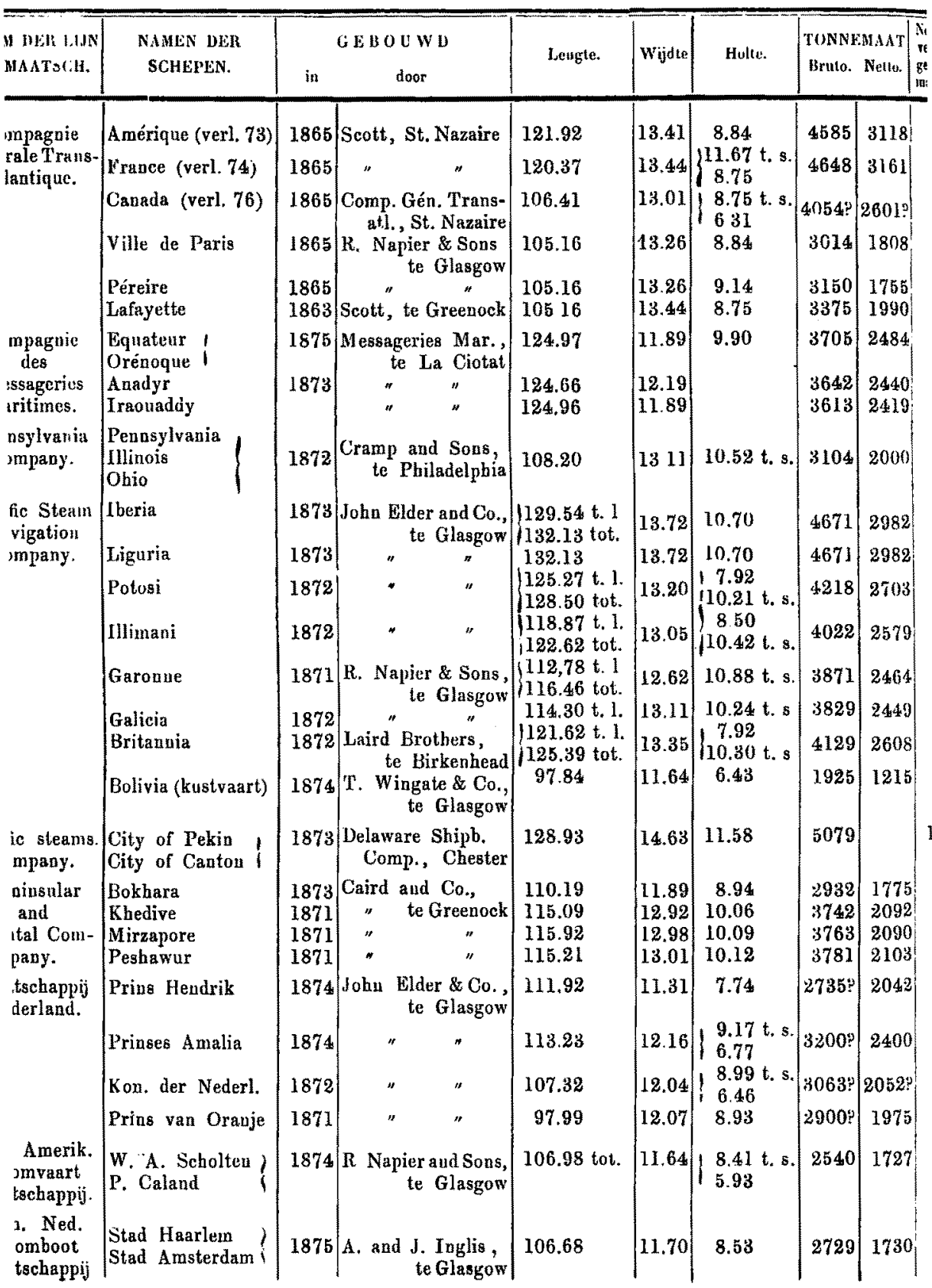

